\title{
Features of the Functioning of Derivatives with the Suffix -Onok in Russian Jargon
}

\author{
Elena A. Makleeva ${ }^{1 *}$ \\ Liana M. Akhmetzyanova ${ }^{1}$ \\ Yan Zhike ${ }^{2}$ \\ ${ }^{1}$ Kazan Federal University, Kazan, Russia \\ ${ }^{2}$ Hunan Normal University, China \\ ${ }^{*}$ Corresponding Author
}

Doi: 10.36941/ajis-2019-0053

\begin{abstract}
The present paper deals with the study of derivational features of noun derivatives with the suffix онок/-ёнок (-onok). The choice of the formant is determined by the fact that the indicated suffix does not produce a large number of word-formation types and, therefore, rarely becomes an object of special studies. However, its colloquial productivity suggests that this formant deserves a closer look. In the literary language, the suffix-онок/-ёнок (-onok) forms the nouns that name cubs, children as representatives of a nationality, social stratum or profession called the motivating word, and a group of derivatives with the suffix -онок/-ёнок(-onok) that has a diminutive-hypocoristic or only affectionate meaning. The material for the study was the data from Unabridged Dictionary of Russian Jargons by V.M. Mokienko, T.G. Nikitina. As a result of application of the method of continuous sampling, we have revealed 42 derivatives with the suffix -Онок/-ёнок (-onok) which were subjected to word-formation and morphemic analysis. It is established that the suffix -онок/-ёнок (-onok) is not very often used in jargon word formation. Two ways of the formation of jargonisms by means of this formant have been revealed: the suffixation proper and semantic derivation. The inclusion of foreign words in the process of formation of derivatives with the formants -онок/-ёнок (-onok) is observed. It has been established that the suffix онок/-ёнок (-onok) in jargon word formation performs the following functions: nominative, evaluativeexpressive, and style-forming. The results can be used, firstly, in lexicography (inclusion of the units with the suffix -Онок (-onok) into explanatory dictionaries of word-formation), and secondly, in linguodidactics (as the subject matter for courses in word formation, Russian as a foreign language).
\end{abstract}

Keywords: suffix, word-formative type, jargon, modification, derivation, semantic derivation, word-formation analysis

\section{Introduction}

According to I. B. Golub, the Russian language is characterized by an exceptional wealth of wordformation resources, which have a wide expressive-stylistic palette. According to the scholar, this is determined by the "developed system of Russian word formation, the productivity of evaluative suffixes that add a variety of expressive colors to words, and the functional-style fixation of some word-formation patterns" (Golub, 2001).

Interest in the study of word formation does not wane, various aspects are reflected in the works by modern domestic scholars (see, for example, Ulukhanov, 2007; Ukhanova \& Kosova, 2016; Trofimova et al., 2017; Khabibullina, 2015; Guzaerova et al., 2018; Sheidaeva, 1998; 
Spiridonov et al., 2018; and many others.) and foreign researchers (see, for example, (Hippisley, 1998; Steriopolo, 2008; Offord, 2003; Pounder, 2000 and many others).

However, it should be remembered that it is necessary to study not only the literary language, but also the peripheral areas of the language, such as jargons and dialects. The importance of the study of jargon is determined by the fact that jargon as one of the uncodified forms of the national language "is characterized by emotive connotation, expression and special expressiveness, therefore, in the formation of jargonisms, peculiar suffixes are often used, i.e. native speakers of jargon deliberately use the formants that differ from the literary language, which perform a playful or humorous function" (Sung, 2015; Shvedova, 1980).

This paper presents the features of word formation of derivatives with the suffix -онок/-ёнок (onok) in Russian jargonism. The choice of the formant is conditioned by the fact that the specified suffix does not form a large number of word-formative types and for this reason it rarely becomes the object of special studies. However, its productivity, especially in colloquial speech, indicates that the designated formant deserves close study and a detailed description.

Unabridged Dictionary of Russian Jargons by V.M. Mokienko, T.G. Nikitina has been chosen as the study material, which lexicalizes 42 derivatives with the suffix of our concern -онок (-onok) (and also its phonemic variant -ёнок (-yonok)).

\section{Methods}

The main method used while working with Unabridged Dictionary of Russian Jargons is the method of continuous sampling. Also in the course of investigation, the method of word-formation analysis and the method of dictionary definition analysis were used.

\section{Results and Discussion}

The authors of Russian Grammar-80, speaking of nouns with a modifying meaning, refer the suffix -онок/-ёнок (-onok) to the group of suffixes forming the nouns with the meaning of non-adulthood: "the nouns with the suffix -онок (-onok) <..> name a person or an animal characterized by childlishness, lack of maturity" [Russian Grammar], and single out the following subtypes:

1) Nouns motivated by the names of animals, calling the baby animals: зверёнок (zveryonok) - the young of wild animals, совёнок(sovyonok) - owlet, щеглёнок(shcheglyonok) - young goldfinch, оленёнок(olenyonok) = fawn, слонёнок(slonyonok) - baby elephant, волчонок(volchyonok) - wolf cub, etc.;

2) The nouns motivated by the names of persons, denoting "a child - a representative of nationality, social stratum or profession named by a motivating word": турчонок (turchonok) - Turkish child, цыганёнок (tsyganyonok) - Gypsy child, батрачонок (batrachonok) - , казачонок (kazachyonok) - Cossack boy, попенёнок (рореnyonok) baby girl, внучонок (vnuchonok) - grandson, etc.

Among the nouns with subjective-attitudinal meaning, a group of derivatives with the suffix онок (-onok) with a diminutive-affectionate or only affectionate meaning is also distinguished: мальчонок (malchonok) - lad, дошколенок (doshkolenok) - preschooler, etc. [Russian Grammar]. According to the materials of the explanatory dictionary of word formation by T.F. Efremova the suffixal formant-онок/-ёнок (-onok ) has the following meanings:

1. A word-formation unit that forms the nouns with general meaning of a person or animal characterized by childishness, lack of maturity: 1) a cub of animals; 2) a child - a representative of nationality, social stratum, profession, designated by a motivating word;

2. A formative unit that forms masculine nouns with a diminutive or affectionate meaning (Efremova, 2000).

T.F. Efremova, characterizing the theoretical foundations of the construction of The Explanatory Dictionary of the Word-Formation Units of the Russian Language, writes, "Formative categories in this dictionary include: $<\ldots>$ diminutive, magnifying, derogatory suffixal formations of nouns" (Efremova, 2000). However, in this case, the prevailing morphemic nature of Russian wordformation which is expressed in its ability to convey word-formation meanings with the help of 
morphemes, like grammatical ones, is not taken into account.

According to the traditions of the Kazan Linguistic School (KLS), we refer the suffixes of subjective evaluation to word formation.

Unabridged Dictionary of Russian Jargons by V.M. Mokienko, T.G. Nikitina (Mokienko \& Nikitina, 2000) fixes 36 derivatives with the suffix -онок/-ёнок (-onok/-yonok) and 6 derivatives in the plural with the suffix -ат(a)/-ята(a) (-at(a)/-yata(a).

Of the 42 derivatives with this suffix, only four designate cubs of animals: моргушонок (morgushonok) (Ofen. Ягнёнок - lamb (from Моргуша Ofen. Овца - sheep, баран - he-sheep)), мозёнок (mozyonok) (Ofen. Козлёнок (kozlyonok) - baby goat (from Моза)), хрунёнок (khrunyonok) (Ofen. Поросёнок (porosyonok) - piggy (from хрунья (khrunya) Ofen. Свинья swine)), шкапёнок (shkapyonok) (1. Criminal Жеребёнок (zherebyonok) - colt (from Шкапа Criminal Ironic. 2. Лошадь - horse)).

Eleven derivatives corresponding to the names of animal cubs in the literary language in jargon represent the result of semantic or morphemic derivation, and the derivatives can denote a face (мышонок (1. Criminal. A picker (usually young). 2. Arrest. A disciplined, not penalized prisoner. 3. Criminal. A drunk man), фразанёнок (phazanyonok) - a young pheasant (Army. Ironical. Young soldier of the spring draft (from Фазан 4. Army. Pejorative. A soldier of military service from a year to 1.5 years // Young soldier of the spring draft)), крысяma (krysyata) - baby rats (Criminal jargonism. Pejorative. Extramarital children of a single mother (usually a deserted drunkard), волчонок (volchonok) - wolf cub (1. Prisoner. Young convict who overrides authorities), индюшата (indyushata) - turkey poults (pl. Mus., humorous. Musicians performing alternative music etc.)), and an item (медвежонок (medvezhonok) - teddy bear (Criminal. Сейфр - a metal box for storing money // Small-sized safe (From Медведь - Bear)), крабёнок (krabyonok) (Narcotic. Снокарб (a psychostimulant, hallucinogenic drug), ymяma (utyata) - ducklings (pl. Criminal. Humorous. Резиновые сапоги - rubber boots, etc.), гусёнок(gusyonok) - gosling (Criminal. Welding machine for breaking up safes), волчонок (volchonok) - wolf cub (2. more often plural for US dollar), цыплёнок (tsyplyonok)- spring chicken (3. pl. Criminal for Ботинки - Boots. 4. pl. Criminal., mil. Humorous for Патроны - Cartridges), etc.). Semantic derivation is also found in the names of mushrooms: опёнок с опятами (opyonok s opyatami) honey mushrooms (Criminal. for Револьвер с патронами - a Revolver with cartridges (< by analogy with Маслёнок с маслятами (Maslyonok, maslyata) - butter mushrooms)).

In a number of examples, a derivative word standing for the name of a person acquires only the meaning of maturity that is characteristic of the suffix -онок/-ёнок (-onok/-yonok): быдлёнок (bydlyenok) (The term of abuse. 1. the child of a prostitute. 2. a demented child. 3. Youth. A student of vocational school (from. (from Быдло - Cattle 2. Abuse. Feeble-minded, stupid, ill-cultured man)), ваучерёнок (voucheryonok) (Youth. Ironical. Young businessman (from Ваучер - Voucher.)), лащёнок (lashchyonok) (Ofen. Ребёнок. Child. (from Лащина. Ofen. Парень, юноша а boy, young man)), корючонок (koryuchonok) (Ofen. Девочка - Girl. (from Корюк, корюка (koryuk, koryukha), from Ofen. Девушка - Girl).

A derivative characterized by the meaning of diminution was lexicalized: скулёнок (skulyonok) (Criminal. Small stash pocket (from Скула. (Skula). Criminal. 1. Inside welt pocket)). In addition, a number of derivative words differs from those produced only by the presence of evaluativity: рубчонок (rubchonok) (Youth. Ironic. Рубль - Ruble), жигулёнок (zhigulyonok) (1. car make Zhiguli).

We can conclude that borrowed words are common in the process of forming new lexemes with this suffix: бэбиёнок (бэбёнок) (bebyonok) (Ребёнок - Child (from English bаbу)), киндарёнок (kindaryonok) (Youth. Humorous. Ребёнок - Baby (from Киндер) (from German Kinder)), чайлдёнок (chaildyonok) (Youth. Ребёнок (from English child)), чилдрёнок (childryonok) (Youth. Humorous. Ребёнок (from English children)), герлёнок (gerlyonok) (Youth. Девушка, девочка (from English girl)), бейбёнок (beibyonok) (Youth. 1. Ребёнок. 2. Девушка (from English baby)), пиплёнок (ріplyonok) (Ребёнок - Baby (from English people)). These derivatives designate a child (less often - a girl), thus expressing the meaning of infantility that is characteristic of the suffix онок/-ёнок (-onok / -yonok).

In addition, one derivative formed by means of univerbalization was fixed: кесарёнок 
(kesaryonok) - C-section baby (Medical, A baby who was delivered by Cesarean section).

\section{Summary}

The word formation analysis of the derivatives with the suffix - онок (-onok) allows for the following conclusions.

On the whole, the suffix-онок (-onok) is not frequent in use for the formation of jargons, which can be explained by the expression of gentleness inherent in it, which is not characteristic of jargon (for example, A. I. Solzhenitsyn writes about the peculiarities of the prison language, "The language of the prisoners loves and stubbornly conducts these inserts of pejorative suffixes: not mamb, but мамка; not больница, but больничка; not свидание, but свиданка; not помилование, but помиловка; not вольный, but вольняшка." (Solzhenitsyn, 1991).

Jargonisms with the suffix -онок (-onok) have two main ways of derivation:

1) suffixation proper, including repeated complexification by means of the suffix of the same stem, generating homonymy,

2) semantic derivation.

In jargonism formation, to reach expressivity is possible not only via the use of formants with an emotionally evaluative connotation, but also due to the presence of homonymous relations between jargon derivatives and literary words. Such formations have a high potential for expressiveness and can create a pun effect.

\section{Conclusions}

Thus, as a result of the study, it was found that Russian jargon is derived by means of the suffix онок/-ёнок (-onok/yonok) according to the same patterns as literary words, but jargon practically does not express endearment. In addition to suffixation itself, semantic derivation plays an important role. Suffixes perform nominative, evaluative-expressive and style-forming functions in jargons.

The obtained results can be used, firstly, in lexicography (inclusion of the units with the suffix -онок/-ёнок (-onok/-yonok) into explanatory dictionaries and explanatory dictionaries of wordformations), and secondly, in linguodidactics (as a subject matter for courses in word formation, the Russian language as a foreign).

\section{Acknowledgements}

The work is performed according to the Russian Government Program of Competitive Growth of Kazan Federal University.

\section{References}

Efremova, T. F. (2000). Modern Dictionary of the Russian Language. Explanatory and Word-Formation. - M.: Rus. Yaz.,. - V. 1: A-O. - 1209 p. - URL: https://classes.ru/all-russian/russian-dictionary-Efremova-term61375.htm, free.

Golub, I. B. (2001). Stylistics of the Russian Language. The third edition, extended. - M.: Rolf, -448 p.

Guzaerova, R. R., Sabolova, D., \& Kosova, V. A. (2018). Russian feminine nouns with suffix -k(a) in the modern mediaspace. Revista San Gregorio, 25, 37-42.

Hippisley, A. R. (1998). Indexed stems and Russian word formation: a network morphology account of Russian personal nouns. Linguistics, 36(6), 1093-1124.

Khabibullina, E. V. (2015). Substandard Derivations as Objects of System Analysis: Derivational Homonyms. XLinguae European Scientific Language Journal January, 8(1), 50-56.

Mokienko, V. M., \& Nikitina, T. G. (2000). Unabridged Dictionary of Russian Jargons. - SPb: Norint. - 720 p.

Offord, D. (2003). Using Russian: A Guide to Contemporary Usage. Cambridge University Press, - 205 p.

Pounder, A. (2000). Process and Paradigms in Word-Formation Morphology. De Gruyter Mouton, - 744 p.

Sheidaeva, S. G. (1998). The Category of a Subjective Evaluation in the Russian Languag. Thesis for Doctor of Philology. - Izhevsk. - 275 p. 
Shvedova, N. Y. (1980). Russian Grammar: In Two Volumes. Editor-in-Chief. - M.: Nauka,. - V. 1: Phonetics. Phonology. Stress. Intonation. Word Formation. Morphology. - 783 p. - URL: http://www.rusgram.narod.ru/380-432.html\#428, free.

Solzhenitsyn, A. I. (1991). Short Collected Works. Vol.6: Arkhipelag GULAG, 1918-1956: Experience of Literary Research: [Vol.2: Part 3-4]. - M.: INKOM NV, - 574 p.

Spiridonov, A. V., Galiulina, I. R., \& Sheykhi, H. (2018). Structural-semantic and functional-stylistic characteristics of Vasily Aksenov's new coined words in the 80's (early emigration period). Modern Journal of language teaching methods, 8(11), 376-381.

Steriopolo, O. (2008). Form and Function of Expressive Morphology: A Case Study of Russian. - 204 P. - URL: http://www.steriopolo.com/download/FORM_AND_FUNCTION_ed.pdf, свободный.

Sung, M. (2015). Compressive Nominations with Domain Semantics in Russian Jargons: Dissertation for Candidate of Philological Sciences.- Kazan, - 213 p.

Trofimova, A. V., Kosova V. A., \& Antonakova, D. (2017). Russian postural verbs of putting as means of spatial thinking verbalization. AD ALTA: Journal of interdisciplinary Research, (07/02-II), 263-266.

Ukhanova, T. V., \& Kosova, V. A. (2016). Russian adjectives with confixes from an anthropocentric viewpoint. Journal of Language and Literature, 7(2), 328-331.

Ulukhanov, I. S. (2007). Derivational Semantics in the Russian Language and the Principles of its Description. M.: URSS,. $-255 \mathrm{p}$. 